\title{
Determinan Pernikahan Usia Dini pada Remaja
}

\author{
Eva Erna Juliawati ${ }^{1}$, Astrid Novita ${ }^{2}$, Rita Ayu Yolandia ${ }^{3}$ \\ ${ }^{1,2,3}$ Program Studi Kebidanan Program Sarjana Terapan Departemen Kebidanan \\ Sekolah Tinggi Ilmu Kesehatan Indonesia Maju \\ Jln. Harapan Nomor 50, Lenteng Agung - Jakarta Selatan 12610 \\ Email: ${ }^{1}$ evaernaedogawa97@gmail.com
}

\section{Editor: ALR}

Diterima: 28/09/2021

Direview: 23/11/2021

Publish: 01/12/2021

\section{Hak Cipta:}

(C)2021 Artikel ini memiliki akses terbuka dan dapat didistribusikan berdasarkan ketentuan Lisensi Atribusi Creative Commons, yang memungkinkan penggunaan, distribusi, dan reproduksi yang tidak dibatasi dalam media apa pun, asalkan nama penulis dan sumber asli disertakan. Karya ini dilisensikan di bawah Lisensi Creative Commons Attribution Share Alike $\mathbf{4 . 0}$ Internasional.

\section{A B S T R A C T}

Introduction: According to the Marriage Law, Number 16 of 2019 article 7 paragraph (1) early marriage is a marriage that is carried out before a person reaches $\leq 19$ years of age.

Objectives: The purpose of this study is to determine the determinants of early marriage in adolescents. The determinants used in this study are economic factors, environmental factors, sociocultural factors, mass media, as well as views and beliefs.

Method: This study used a design cross-sectional, with a simple random sampling technique. And determining the sample using the Lemeshow formula to obtain a sample size of 50 respondents.

Result: The results showed that 27 respondents (54\%) were married aged 16-17 years, 30 respondents $(60 \%)$ had low-income economic factors <UMK, 27 respondents $(54 \%)$ had bad environmental factors, 29 respondents $(58 \%)$ had social negative culture, 31 respondents (65\%) were exposed to mass media, 28 respondents $(56 \%)$ had negative views and beliefs.

Conclusion: The results of the test Chi-Square showed that there was a significant relationship between early marriage among adolescents with economic factors $\mathrm{p}$-value $=0.013$ and $\mathrm{OR}=5.444(95 \% \mathrm{CI}$ 1.584-18.714), environmental factors $\mathrm{P}$-value $=0.026$ and $\mathrm{OR}=4.453$ (95\% CI $1.353-14.653)$, socio-cultural P-Value $=0.027$ and $\mathrm{OR}=$ 4.444 (95\% CI 1.337-14.769), mass media P-Value $=0.028$ and OR $=4.550(95 \% \mathrm{CI} 1.335-15,503)$, views and beliefs of $\mathrm{P}-$ Value $=0.002$ and $\mathrm{OR}=8.000(95 \%$ CI 2.247- 28.477).

Keywords: adolescent, determinants, early marriage 


\section{Pendahuluan}

Banyak kasus pernikahan dini atau muda terjadi di berbagai belahan dunia dengan berbagai latar belakang yang menimbulkan dampak dan risiko dari pernikahan usia dini sehingga akan berperan dalam meningkatkan angka kematian ibu dan bayi. ${ }^{1}$ Menurut UU Perkawinan No.1 Tahun 1974, perkawinan merupakan ikatan jasmani dan rohani antara lakilaki dan perempuan sebagai suami-istri bertujuan menciptakan rumah tangga yang bahagia dan abadi bersumber Tuhan Yang Esa. ${ }^{2}$ Menurut UU Perkawinan Nomor 16 Tahun 2019 pasal 7 ayat (1) pernikahan dini adalah pernikahan yang dilakukan sebelum seseorang mencapai usia $\leq 19$ tahun. Menurut Suparyanto, perkawinan dini merupakan salah satu bentuk ikatan/kawin dimana salah satu pasangan berumur 19 tahun atau masih mengikuti proses pendidikan disekolah. ${ }^{3}$

Pernikahan yang berlangsung pada usia dini umumnya akan menimbulkan masalah baik secara fisiologis, psikologis maupun sosial ekonomi. Dampak dan resiko yang timbul akibat pernikahan dini pada umumnya lebih banyak dialami oleh perempuan. Diantaranya dari aspek kesehatan yaitu terjadinya infeksi pada kandungan, penyakit menular seksual, kanker mulut rahim, keguguran dan masalah kesehatan reproduksi lainnya, hal ini dikarenakan organ reproduksi perempuan belum siap menerima kehamilan sehingga dapat menimbulkan berbagai komplikasi. Perempuan muda yang sedang hamil, berdasarkan penelitian akan mengalami beberapa hal, seperti akan mengalami pendarahan, keguguran, dan persalinan yang lama atau sulit. ${ }^{4}$ Perempuan usia 15-19 tahun memiliki kemungkinan dua kali lebih besar meninggal saat melahirkan dibandingkan yang berusia 20-25 tahun, sedangkan usia di bawah 15 tahun kemungkinan meninggal bisa lima kali lebih besar dibanding yang berusia 20-25 tahun. Meski ada beberapa dampak positif, namun tidak seimbang dengan lebih banyak dampak negatif. ${ }^{2}$

United Nations Children's Fund (UNICEF), menyatakan ada 765 juta anak laki-laki dan perempuan menikah di antara 2,2 miliar anak di Dunia secara global. Sekitar 1 dari setiap 5 perempuan berusia 20-24 tahun menikah sebelum mereka berulang tahun ke-18. ${ }^{5}$ UNICEF pada tahun 2018 juga menyatakan 1 dari 9 anak perempuan menikah di Indonesia diperkirakan sekitar $21 \%$ perempuan muda (usia 20 hingga 24 tahun) yang menikah sebelum berusia 18 tahun. Angka ini mengalami penurunan dibandingkan 10 tahun yang lalu yang angkanya mencapai 25\%. Jumlah yang terbanyak terdapat di negara-negara Asia Selatan diikuti SubSahara Afrika. ${ }^{6}$ Menurut data Kementerian Pemberdayaan Perempuan dan Perlindungan Anak (Kemen PPPA), Indonesia termasuk negara dengan persentase pernikahan usia dini tinggi dengan rangking 37 di dunia dan tertinggi kedua di Asia Tenggara. ${ }^{7}$

Menurut Kementerian Pemberdayaan Perempuan dan Perlindungan Anak/ Kemen PPPA, data Badan Pusat Statistik (BPS) terkait proporsi perempuan yang berstatus kawin sebelum umur 18 menurut Provinsi tahun 2019. Pada 22 Provinsi prevalensi perkawinan anak masih diatas rata-rata nasional. Provinsi dengan prevalensi perkawinan anak tertinggi adalah Kalimantan Selatan (21,2\%), Kalimantan Tengah (20,2\%), Sulawesi Barat (19,2\%), Kalimantan Barat (17,9\%) dan Sulawesi Tenggara (16,6\%). Artinya 1 dari 9 anak kawin sebelum berusia 18 tahun. Dari semua data tersebut, diambil rata-rata nasional. Dengan demikian, tingkat perempuan berstatus kawin dibawah usia 18 tahun di Indonesia adalah $10,82 \% .{ }^{8}$ Dalam 10 tahun, prevalensi perkawinan anak di daerah pedesaan menurun sebanyak $5,76 \%$, sementara prevalensi di daerah perkotaan hanya menurun $<1 \%$. ${ }^{6}$ 


\section{SIMFISIS Jurnal Kebidanan Indonesia}

Volume 01, Nomor 02, November 2021

Menurut Kepala BKKBN Kalimantan Barat, dari 14 Kabupaten di Kalimantan Barat, persentase perkawinan pertama bagi perempuan di umur 10 tahun keatas di kota Pontianak sudah menduduki peringkat terakhir dengan angka 7,76\% perkawinan di usia $\leq 16$ tahun dan sebesar 14,58\% di usia 17-18 tahun, namun di kabupaten lain pernikahan anak masih cukup tinggi. ${ }^{9}$ Sementara data jumlah remaja wanita yang menikah di usia dini yang didapat dari KUA Kecamatan Pontianak Barat tahun 2018 sebesar (5,2\%) pada tahun 2019 mengalami kenaikan menjadi $(9,6 \%){ }^{10}$

Adapun faktor penyebab pernikahan usia dini yaitu, paksaan dari orang tua, pergaulan bebas, rasa keingintahuan tentang dunia seks, faktor ekonomi, faktor lingkungan, dan rendahnya pendidikan. Menurut Kumalasari \& Andhya, faktor penyebab pernikahan usia dini adalah faktor sosial budaya, desakan ekonomi, tingkat pendidikan, sulit mendapat pekerjaan, media massa, agama serta pandangan dan kepercayaan. ${ }^{2}$

Ekonomi dan kemiskinan memberikan andil bagi berlangsungnya pernikahan usia dini. Hal ini terjadi karena keadaan keluarga yang hidup di garis kemiskinan, tidak mampu membiayai sekolah anaknya sehingga orang tua ingin anaknya segera menikah, ingin lepas tanggung jawab, dan orang tua berharap setelah anaknya menikah akan mendapat bantuan secara ekonomi. Menurut Hotchkiss, dengan melakukan analisis terhadap data survei rumah tangga di Serbia menunjukkan bahwa pernikahan pada usia muda terjadi pada anak perempuan dengan sosial ekonomi keluarga yang rendah. ${ }^{11}$

Menurut Ahmadi, A dan Nur Uhbiyati, lingkungan adalah seluruh kondisi yang ada disekitar manusia dan pengaruhnya yang dapat mempengaruhi perkembangan dan perilaku orang atau kelompok. ${ }^{12}$ Menurut Statistik, lingkungan seperti orang tua, saudara-saudara dan kerabat, dan pergaulan dengan teman turut memberikan pengaruh dalam diri remaja juga turut mempengaruhi perkawinan usia muda. ${ }^{13}$

Menurut Sachdeva et al, sosial budaya merupakan suatu pola perilaku yang karakteristik dalam suatu masyarakat berupa kebiasaan, tata kelakuan hukum, dan nilai-nilai kemasyarakatan yang dianut dan dipercaya dalam suatu kelompok. ${ }^{14}$ Menurut teori Sociocultural oleh Vygotsy, cara orang dalam menjalani kehidupan sangat dipengaruhi oleh faktor sosial budaya dimana ia hidup. ${ }^{15}$ Media massa adalah "dalam bahasa inggris : mass media" singkatan yang berasal dari media komunikasi massa dalam bahasa inggris mass communication media, yang berarti media massa yaitu sarana penyampaian pesan-pesan, aspirasi masyarakat, sebagai alat komunikasi untuk menyebarkan berita ataupun pesan kepada masyarakat langsung secara luas. ${ }^{16}$ Pandangan dan kepercayaan merupakan suatu cara pandang atau persepsi seseorang mengenai kebiasaan, keyakinan atau kepercayaan seseorang yang diyakini benar adanya. Seperti pandangan dan kepercayaan dari segi agama terhadap pernikahan usia dini pada remaja.

Dari hasil studi pendahuluan melalui wawancara yang dilakukan di KUA Kecamatan Pontianak Barat, pada 10 responden yang menikah di usia $\leq 19$ tahun, dari 10 responden yang menikah muda didapatkan bahwa 3 diantaranya mengatakan alasan menikah di usia dini adalah karena faktor ekonomi seperti dijodohkan karena dapat meringankan beban orang tua. 2 diantaranya menjawab karena faktor lingkungan seperti keinginan diri sendiri, dan hamil di luar nikah dan harus berhenti sekolah, untuk mencegah rasa malu dan menutup aib keluarga sehingga memilih untuk melakukan pernikahan di usia dini. 1 diantaranya menjawab karena sosial budaya seperti orang tua merasa khawatir terkena aib karena anak perempuannya 


\section{SIMFISIS Jurnal Kebidanan Indonesia}

Volume 01, Nomor 02, November 2021

berpacaran dengan laki-laki yang sangat dekat sehingga mengawinkan anaknya, adanya adat atau budaya seperti anak yang dilamar pemuda bila ditolak membuat anaknya susah mendapatkan jodoh. 2 diantaranya menjawab karena media massa seperti sering melihat atau menonton video porno dan indahnya pernikahan di media sosial, 2 diantaranya menjawab karena pandangan dan kepercayaan seperti tidak ingin berpacaran lama-lama agar terhindar dari perbuatan yang dilarang agama, tidak ada batasan usia menikah dan faktor lainnya. Tujuan penelitian ini adalah untuk mengetahui Determinan Pernikahan Usia Dini Pada Remaja.

\section{Metode}

Penelitian ini merupakan penelitian kuantitatif dengan metode survey analitik dan menggunakan pendekatan cross sectional yaitu suatu penelitian untuk mempelajari dinamika kolerasi antara faktor-faktor resiko atau variabel independen dengan efek atau variabel dependen yang diobservasi atau pengumpulan datanya sekaligus secara bersamaan. ${ }^{17}$ Penelitian ini dilaksanakan pada bulan Juli, dan lokasi penelitian di KUA Kecamatan Pontianak Barat Pada Tahun 2020.

Populasi dalam penelitian ini adalah remaja wanita usia 16-19 tahun yang sudah menikah di KUA Kecamatan Pontianak Barat pada Tahun 2019 sebanyak 98 orang. Teknik pengambilan sampel pada penelitian ini adalah simple random sampling. Sampel minimal yang diambil berjumlah 50 sampel dari 98 populasi yang diperoleh menggunakan rumus lemeshow. Instrumen yang digunakan dalam penelitian ini adalah kuesioner. Sebelum digunakan dalam penelitian, instrumen berupa kuesioner yang dibagikan dan diisi oleh 30 responden untuk diuji cobakan untuk menjaga validitas dan reliabilitas dari instrumen tersebut, sehingga maksud dari instrumen menjadi jelas dan mudah dipahami oleh responden. Uji validitas menggunakan SPSS versi 20.

Metode Analisa data yang dapat digunakan dalam penelitian ini adalah analisis univariat dan analisis bivariat. Analisis univariat merupakan analisa setiap variabel penelitian yang dinyatakan dengan bentuk distribusi frekuensi dan persentasi dari setiap variabel. Sedangkan analisis bivariat adalah Untuk mencari hubungan antara dua variable. ${ }^{16}$ Penyajian data dalam penelitian ini yaitu bentuk tabel umum dan dijelaskan secara naratif. Tabel univariat menyajikan data dalam bentuk distribusi frekuensi. Sedangkan tabel bivariat menyajikan nilai p-value dan OR dari hasil uji statistik "Chi- square" dari pengolahan data output yang menggunakan bantuan SPSS statistic windows versi 21. Jika $p$-Value $<0,05$ maka Ho ditolak dan Ha diterima yang berarti terdapat hubungan antara faktor ekonomi, faktor lingkungan, sosial budaya, media massa serta pandangan dan kepercayaan terhadap kejadian pernikahan usia dini pada remaja di kua kecamatan pontianak barat.

\section{Hasil}

Tabel 1. Distribusi Frekuensi Determinan Pernikahan Usia Dini pada Remaja

\begin{tabular}{lcc}
\hline \multicolumn{1}{c}{ Variabel } & Frekuensi (f) & Persentase (\%) \\
\hline Pernikahan Usia Dini Pada Remaja & 27 & 54 \\
Menikah Usia 16-17 tahun & 23 & 46 \\
Menikah Usia 18-19 Tahun & 30 & 60 \\
\hline $\begin{array}{l}\text { Faktor Ekonomi } \\
\text { Pendapatan Rendah } \\
\text { < UMK }\end{array}$ & 20 & 40 \\
Pendapatan Tinggi & & \\
> UMK & & \\
\hline
\end{tabular}




\begin{tabular}{lcc}
\hline Faktor Lingkungan & & \\
Buruk & 27 & 54 \\
Baik & 23 & 46 \\
\hline Sosial Budaya & & 58 \\
Negatif & 29 & 42 \\
Positif & 21 & 65 \\
\hline Media Massa & 31 & 38 \\
Terpapar & 19 & 56 \\
Tidak Terpapar & & 44 \\
\hline Pandangan Dan Kepercayaan & 28 & 22 \\
Negatif & 22 & \\
\hline
\end{tabular}

Berdasarkan tabel 1 dapat dilihat bahwa sebagian besar responden menikah usia 16-17 tahun sebanyak 27 responden (54\%). Sebagian besar responden mempunyai tingkat pengetahuan rendah yaitu sebanyak 73 responden $(73 \%)$. Faktor ekonomi responden sebagian besar berpendapatan rendah <UMK sebnayak 30 responden (60\%). Distribusi frekuensi faktor lingkungan diketahui bahwa sebagian responden memiliki faktor lingkungan buruk sebanyak 27 responden (54\%). Didapatkan responden dengan sosial budaya negativ sebanyak 29 responden $(58 \%)$. Keterpaparan media massa sebanyak 31 responden $(65 \%)$. Hasil distribusi frekuensi pandangan dan kepercayaan diketahui sebanyak 28 responden $(56 \%)$ memiliki pandangan dan kepercayaan yang negativ. Sedangkan sebanyak 22 responden (44\%) memiliki pandangan dan kepercayaan yang positif.

\section{Analisis Bivariat}

Tabel 2. Determinan Pernikahan Usia Dini pada Remaja

\begin{tabular}{|c|c|c|c|c|c|c|c|c|c|}
\hline \multicolumn{10}{|c|}{$\begin{array}{c}\text { Pernikahan Usia Dini Pada } \\
\text { Remaja }\end{array}$} \\
\hline \multirow[t]{2}{*}{ No } & \multirow[t]{2}{*}{ Variabel Penelitian } & \multicolumn{2}{|c|}{$\begin{array}{l}\text { Menikah Usia } \\
\text { 16-17 Tahun }\end{array}$} & \multicolumn{2}{|c|}{$\begin{array}{l}\text { Menikah Usia } \\
\text { 18-19 Tahun }\end{array}$} & \multicolumn{2}{|c|}{ Total } & \multirow[t]{2}{*}{$\begin{array}{c}\text { P- } \\
\text { Value } \\
\end{array}$} & \multirow[t]{2}{*}{$\begin{array}{c}\text { OR } \\
95 \% \mathrm{CI}\end{array}$} \\
\hline & & $\mathbf{F}$ & $\%$ & $\mathbf{F}$ & $\%$ & $\mathbf{F}$ & $\%$ & & \\
\hline \multirow[t]{3}{*}{1} & Faktor Ekonomi & & & & & & & & \\
\hline & $\begin{array}{l}\text { Pendapatan Rendah } \\
\text { <UMK }\end{array}$ & 21 & 70 & 9 & 30 & 30 & 100 & \multirow{2}{*}{0,013} & 5,444 \\
\hline & $\begin{array}{l}\text { Pendapatan Tinggi } \\
>\text { UMK }\end{array}$ & 6 & 30 & 14 & 70 & 20 & 100 & & $(1,584-18,714)$ \\
\hline \multirow[t]{3}{*}{2} & Faktor Lingkungan & & & & & & & & \\
\hline & Buruk & 19 & 70,4 & 8 & 29,6 & 27 & 100 & \multirow{2}{*}{0,026} & 4,453 \\
\hline & Baik & 8 & 34,8 & 15 & 65,2 & 23 & 100 & & $(1,353-14,653)$ \\
\hline \multirow[t]{3}{*}{3} & Sosial Budaya & & & & & & & \multirow{3}{*}{0,027} & \\
\hline & Negatif & 20 & 69 & 9 & 31,3 & 29 & 100 & & 4,444 \\
\hline & Positif & 7 & 33,3 & 14 & 66,7 & 21 & 100 & & $(1,337-14,769)$ \\
\hline \multirow[t]{3}{*}{4} & Media Massa & & & & & & & & \\
\hline & Terpapar & 21 & 67,7 & 10 & 32,3 & 31 & 100 & \multirow{2}{*}{0,028} & 4,550 \\
\hline & Tidak Terpapar & 6 & 31,6 & 13 & 68,4 & 19 & 100 & & $(1,335-15,503)$ \\
\hline \multirow[t]{3}{*}{5} & Pandangan dan Keper & & & & & & & & \\
\hline & Negatif & 21 & 75 & 7 & 25 & 28 & 100 & \multirow[t]{2}{*}{0,002} & 8,000 \\
\hline & Positif & 6 & 27,3 & 16 & 72,7 & 22 & 100 & & $(2,247-28,477)$ \\
\hline
\end{tabular}

Berdasarkan tabel 2 didapatkan hasil analisis bivariat determinan pernikahan usia dini pada remaja, dimana terdapat 5 variabel yang yang dilihat apakah ada hubungan yang signifikatan atau tidak signifikan. 
Pada tabel 2 dapat diketahui sebanyak 30 responden mempunyai faktor ekonomi yang pendapatannya rendah <UMK, sebanyak 21 responden (70\%) menikah di usia 16-17 tahun. Sedangkan dari 20 responden yang mempunyai faktor ekonomi yang pendapatannya tinggi >UMK, sebanyak 14 responden (70\%) menikah di usia 18-19 tahun. Hasil uji statistik Chisquare hubungan faktor ekonomi terhadap pernikahan usia dini pada remaja diperoleh nilai $p$ value $=0,013$. Hasil Uji diperoleh nilai $\mathrm{OR}=5,444$ (95\% CI=1,584-18,714).

Pada tabel 2 dapat diketahui sebanyak 27 responden memiliki faktor lingkungan yang buruk, sebanyak 19 responden (70,4\%) menikah di usia 16-17 tahun. Sedangkan dari 23 responden memiliki faktor lingkungan yang baik, sebanyak 15 responden $(65,2 \%)$ menikah di usia 18-19 tahun. Hasil uji statistik Chi-square hubungan faktor lingkungan terhadap pernikahan usia dini pada remaja diperoleh nilai $p$-value $=0,026$. Hasil Uji diperoleh nilai $\mathrm{OR}=4,453(95 \% \mathrm{CI}=1,353-14,653)$.

Pada tabel 2 dapat diketahui sebanyak 29 responden memiliki sosial budaya yang negatif, sebanyak 20 responden (69\%) menikah di usia 16-17 tahun. Sedangkan dari 21 responden memiliki sosial budaya yang positif, sebanyak 14 responden $(66,7 \%)$ menikah di usia 18-19 tahun. Hasil uji statistik Chi-square hubungan sosial budaya terhadap pernikahan usia dini pada remaja diperoleh nilai $p$-value $=0,027$. Hasil $\mathrm{Uji}$ diperoleh nilai $\mathrm{OR}=4,444(95 \%$ $\mathrm{CI}=1,337-14,769)$.

Pada tabel 2 dapat diketahui sebanyak 31 responden terpapar media massa, sebanyak 21 responden $(67,7 \%)$ menikah di usia 16-17 tahun. Sedangkan dari 19 responden yang tidak terpapar media massa, sebanyak 13 responden $(68,4 \%)$ menikah di usia 18-19 tahun. Hasil uji statistik Chi-square hubungan media massa terhadap pernikahan usia dini pada remaja diperoleh nilai $p$-value $=0,028$. Hasil $\mathrm{Uji}$ diperoleh nilai $\mathrm{OR}=4,550 \quad(95 \% \mathrm{CI}=1,335-15,503)$.

Pada tabel 2 dapat diketahui sebanyak 28 responden memiliki pandangan dan kepercayaan yang negatif, sebanyak 21 responden (75\%) menikah di usia 16-17 tahun. Sedangkan dari 22 responden memiliki pandangan dan kepercayaan positif, 16 responden (72,7\%) menikah di usia 18-19 tahun. Hasil uji statistik Chi-square hubungan pandangan dan kepercayaan terhadap pernikahan usia dini pada remaja diperoleh nilai $p$-value $=0,002$. Hasil Uji diperoleh nilai $\mathrm{OR}=8,000$ (95\% CI=2,247-28,477).

\section{Pembahasan}

\section{Faktor Ekonomi Terhadap Pernikahan Usia Dini pada Remaja}

Hasil uji Chi-square menunjukan hubungan faktor ekonomi terhadap pernikahan usia dini pada remaja diperoleh nilai $p$-value $=0,013$ artinya $p$-value $<a(0,05)$ sehingga dapat disimpulkan hipotesis nol (H0) ditolak dan hipotesis alternatif (Ha) diterima yang berarti ada hubungan yang signifikan antara faktor ekonomi terhadap pernikahan usia dini pada remaja. Hasil Uji Odds Ratio menunjukan nilai OR=5,444 (95\% CI=1,584-18,714) artinya responden yang mempunyai faktor ekonomi yang pendapatannya rendah <UMK akan meningkatkan resiko pernikahan usia dini pada remaja sebanyak 5,444 kali lebih besar dibandingkan responden yang mempunyai faktor ekonomi yang pendapatannya tinggi >UMK.

Ekonomi dan kemiskinan berkontribusi pada pernikahan anak usia dini. Hal ini terjadi karena kondisi keluarga yang hidup dalam garis kemiskinan, tidak mampu membiayai sekolah anaknya, sehingga orang tua ingin anaknya segera menikah, mau meninggalkan tanggung jawabnya, dan orang tua berharap setelah anaknya menikah akan mendapatkan bantuan 


\section{SIMFISIS Jurnal Kebidanan Indonesia}

ekonomi. Menurut Hotchkiss dengan menganalisis data survei rumah tangga di Serbia menunjukkan bahwa perkawinan pada usia muda terjadi pada anak perempuan dengan kondisi sosial ekonomi keluarga rendah. ${ }^{11}$

Penelitian yang dilakukan oleh Nazli Halwani Pohan yang menyatakan bahwa ada hubungan yang bermakna antara status ekonomi dengan pernikahan usia dini pada remaja putri diperoleh nilai $p$-value $0,003<\mathrm{a}(0,05)$ dan OR sebesar 3,285 artinya responden dengan status ekonominya rendah kemungkinan berisiko 3,2 kali menikah dini dibanding responden yang status ekonominya tinggi. ${ }^{18}$

Penelitian yang sejalan dilakukan oleh I Nyoman Adi Pramana yang menyatakan bahwa ada hubungan yang bermakna antara faktor ekonomi dengan pernikahan usia dini pada remaja wanita diperoleh nilai $p$-value $0,000<\mathrm{a}(0,05)$ dan OR sebesar 51,000 artinya semakin besar pengaruh faktor ekonomi maka memiliki resiko 51,000 kali lebih besar untuk semakin muda umur remaja melakukan pernikahan usia dini. ${ }^{19}$

Penelitian yang sejalan juga dilakukan oleh Rotua Simanjuk yang menyatakan ada hubungan antara status ekonomi dengan pernikahan usia dini pada remaja putri. Hal ini dibuktikan dari hasil perhitungan uji korelasi dapat diketahui bahwa nilai $p$-value $0,003<a$ $(0,05)$ serta OR sebesar 3,285 yang berarti bahwa remaja putri yang status ekonomi rendah mempunyai resiko 3,285 kali menikah dini dibandingkan remaja putri yang status ekonomi tinggi. ${ }^{20}$

Berdasarkan paparan yang telah dijelaskan, peneliti mengungkapkan bahwa peran tenaga kesehatan sangat dibutuhkan dalam rangka memberikan edukasi kepada remaja putri dan orang tua tentang resiko dan dampak perkawinan pada usia dini sehingga dapat mencegah pernikahan dini dan peran pemerintah untuk menanggulangi kemiskinan yang terjadi dengan menyediakan dan mengarahkan yang putus sekolah untuk mengikuti kursus keterampilan.

\section{Faktor Lingkungan Terhadap Pernikahan Usia Dini pada Remaja}

Hasil uji Chi-square menunjukan hubungan faktor lingkungan terhadap pernikahan usia dini pada remaja diperoleh nilai $p$-value $=0,026$ artinya $p$-value $<a(0,05)$ sehingga dapat disimpulkan hipotesis nol (H0) ditolak dan hipotesis alternatif (Ha) diterima yang berarti ada hubungan yang signifikan antara faktor lingkungan terhadap pernikahan usia dini pada remaja. Hasil Uji Odds Ratio menunjukan nilai OR=4,453 (95\% CI=1,353-14,653) artinya responden yang memiliki faktor lingkungan yang buruk akan meningkatkan resiko pernikahan usia dini sebanyak 4,453 kali lebih besar dibandingkan responden yang memiliki faktor lingkungan yang baik.

Menurut Ahmadi, A dan Nur Uhbiyati lingkungan adalah seluruh kondisi yang ada disekitar manusia dan pengaruhnya yang dapat mempengaruhi perkembangan dan prilaku orang atau kelompok. ${ }^{12}$ Lingkungan merupakan tempat pemukiman dengan segala sesuatunya dimana organismenya hidup beserta keadaan dan kondisi yang secara langsung maupun tidak dapat diduga ikut mempengaruhi tingkat lingkungan. ${ }^{21}$ Lingkungan seperti orang tua, saudarasaudara dan kerabat, dan pergaulan dengan teman turut memberikan pengaruh dalam diri remaja juga turut mempengaruhi perkawinan usia muda. ${ }^{13}$ Remaja yang mempunyai lingkungan negatif berhubungan sebab akibat dengan kejadian pernikahan usia dini. Lingkungan remaja yang negatif mempengaruhi kejadian pernikahan usia dini, dibandingkan dengan remaja dengan lingkungan positif. 
Penelitian yang dilakukan oleh Nurlaila Fitrianis dari 7 responden yang lingkungan pergaulannya baik, sebanyak 6 orang $(18,2 \%)$ responden yang menikah usia dini $>16$ tahun dan 1 orang $(3,0 \%)$ responden yang menikah $\leq 16$ tahun. Sedangkan dari 26 responden yang lingkungan pergaulannya tidak baik, sebanyak 3 orang $(9,1 \%)$ responden yang menikah $>16$ tahun dan 23 orang $(69,7 \%)$ responden yang menikah $\leq 16$ tahun. Berdasarkan hasil uji Chisquare antara variabel lingkungan pergaulan dengan pernikahan dini diperoleh $p$-value 0,000 $<a(0,05)$ yang artinya terdapat hubungan yang bermakna antara lingkungan pergaulan terhadap pernikahan dini. ${ }^{22}$

Penelitian yang sejalan dilakukan oleh Resti Amalia dari 78 responden yang lingkungannya kurang baik sebanyak 53 orang $(48,2 \%)$ yang menikah dini dan 25 orang $(22,7 \%)$ responden tidak menikah dini. Sedangkan dari 32 responden yang lingkungannya baik, sebanyak 14 orang. $(12,7 \%)$ responden yang menikah dini dan 18 orang $(32 \%)$ responden yang tidak menikah dini. Berdasarkan hasil uji Chi-square antara variabel lingkungan dengan pernikahan dini pada remaja, diperoleh nilai p-value $0,032<$ a $(0,05)$ yang artinya maka $\mathrm{H} 0$ ditolak, sehingga dapat disimpulkan ada hubungan yang bermakna antara lingkungan dengan pernikahan dini pada remaja. ${ }^{23}$

Penelitian yang sejalan juga dilakukan oleh Eka Yuli Handayani dari 96 responden yang lingkungannya negatif, sebanyak 70 orang $(33,3 \%)$ responden yang menikah dini dan 140 orang $(66,7 \%)$ responden yang tidak menikah dini. Sedangkan dari 114 responden lingkungan nya positif, sebanyak 70 orang $(33,3 \%)$ responden yang menikah dini, dan 140 orang $(66,7 \%)$ responden yang tidak menikah dini. Berdasarkan hasil uji Chi-square antara variabel lingkungan dengan pernikahan usia dini, diperoleh nilai $p$-value $0,027<a(0,05)$ yang artinya maka $\mathrm{HO}$ ditolak, sehingga dapat disimpulkan ada hubungan yang bermakna antara lingkungan dengan pernikahan usia dini. ${ }^{24}$

Berdasarkan paparan yang telah dijelaskan, peneliti mengungkapkan bahwa peran orang tua diperlukan untuk meningkatkan kemampuan dalam berkomunikasi dengan remaja secara terbuka agar anak memiliki rasa percaya dan mudah diajak bicara tentang masalah yang dihadapinya serta memantau hubungan dan lingkungan dimana remaja putri berada dan peran tenaga kesehatan juga diperlukan dalam mencegah pergaulan bebas dengan memberikan penyuluhan bahwa salah satu dampak pergaulan bebas adalah kehamilan yang pada akhirnya dapat berujung pada pernikahan dini.

\section{Sosial Budaya Terhadap Pernikahan Usia Dini pada Remaja}

Hasil uji Chi-square menunjukan hubungan sosial budaya terhadap pernikahan usia dini pada remaja diperoleh nilai $p$-value $=0,027$ artinya $p$-value $<a(0,05)$ sehingga dapat disimpulkan hipotesis nol (H0) ditolak dan hipotesis alternatif (Ha) diterima yang berarti ada hubungan yang signifikan antara sosial budaya terhadap pernikahan usia dini pada remaja. Hasil Uji Odds Ratio menunjukan nilai OR=4,444 (95\% CI=1,337-14,769) artinya responden yang memiliki sosial budaya yang negatif akan meningkatkan resiko pernikahan usia dini sebanyak 4,444 kali lebih besar dibandingkan responden yang memiliki sosial budaya yang positif.

Sosial Budaya (Sociocultural) adalah suatu pola tingkah laku yang menjadi ciri khas dalam suatu masyarakat berupa kebiasaan, kode etik hukum, dan nilai-nilai sosial yang di anut dan di percayai dalam suatu kelompok. ${ }^{14}$ Budaya yang mendukung pernikahan dini, karena perjodohan sering dilakukan mengikuti tradisi orang tua, jika mempunyai anak perempuan 
maka anak perempuan harus cepat menikah untuk menghindari pergaulan bebas, jika terlambat menikah diyakini sulit mendapatkan keturunan, dan anak perempuan tidak diwajibkan untuk melanjutkan pendidikan yang lebih tinggi karena bisa menimbulkan perawan tua. Hal ini menimbulkan lebih banyak motivasi, keluarga untuk menikahkan putri mereka lebih awal. ${ }^{25}$

Menurut penelitian yang dilakukan oleh Nazli Halwani Pohan dari 70 responden yang percaya pada budaya sebanyak, 33 orang $(73,33 \%)$ responden yang menikah dini dan 37 orang $(41,11 \%)$ responden yang belum menikah. Sedangkan dari 65 responden yang tidak percaya pada budaya sebanyak, 12 orang $(26,67 \%)$ responden yang menikah dini dan 53 orang $(58,89 \%)$ responden yang belum menikah. Berdasarkan hasil uji Chi-square antara variabel sosial budaya dengan pernikahn usia dini, diperoleh nilai $p$-value $0,001<\mathrm{a}(0,05)$ yang artinya maka H0 ditolak, sehingga dapat disimpulkan ada hubungan yang bermakna antara sosial budaya terhadap pernikahan dini pada remaja putri. ${ }^{18}$

Penelitian yang sejalan dilakukan oleh Nova Arikhman dari 36 responden yang mendukung budaya sebanyak 26 orang $(72,2 \%)$ responden yang menikah dini dan 10 orang $(27,8 \%)$ responden tidak menikah dini. Sedangkan dari 31 responden yang tidak mendukung budaya sebanyak, 6 orang $(19,4 \%)$ responden yang menikah dini dan 25 orang $(80,6 \%)$ responden yang tidak menikah dini. Berdasarkan hasil uji Chi-square antara variabel budaya dengan pernikahan dini, diperoleh nilai $p$-value $0,000<\mathrm{a}(0,05)$ yang artinya terdapat hubungan yang bermakna antara budaya terhadap pernikahan dini. ${ }^{26}$

Penelitian yang sejalan juga dilakukan oleh I Nyoman Adi Pramana yang menyatakan bahwa ada hubungan yang bermakna antara faktor sosial budaya terhadap pernikahan usia dini pada remaja wanita diperoleh nilai p-value 0,000<a $(0,05)$ dan OR sebesar 2,667 artinya semakin besar pengaruh faktor sosial budaya maka memiliki resiko 2,667 kali lebih besar untuk semakin muda umur remaja melakukan pernikahan usia dini. ${ }^{19}$

Berdasarkan paparan yang telah dijelaskan, peneliti mengungkapkan bahwa peran tenaga kesehatan sangat dibutuhkan untuk dapat memberikan penyuluhan kepada masyarakat tentang dampak pernikahan dini agar mereka menyadari bahwa menikah diusia 21 tahun menurut UU perkawinan bukanlah aib melainkan usia yang ideal untuk mulai bereproduksi dan tidak ada lagi pernikahan dini yang terjadi seiring berjalannya waktu akibat rendahnya pengetahuan remaja putri dan orang tua tentang pernikahan dini.

\section{Media Massa Terhadap Pernikahan Usia Dini pada Remaja}

Hasil uji Chi-square menunjukan hubungan media massa terhadap pernikahan usia dini pada remaja diperoleh nilai $p$-value $=0,028$ artinya $p$-value $<a(0,05)$ sehingga dapat disimpulkan hipotesis nol (H0) ditolak dan hipotesis alternatif (Ha) diterima yang berarti ada hubungan yang signifikan antara media massa terhadap pernikahan usia dini pada remaja. Hasil Uji Odds Ratio menunjukan nilai $\mathrm{OR}=4,550(95 \% \mathrm{CI}=1,335-15,503)$ artinya responden yang terpapar media massa akan meningkatkan resiko pernikahan usia dini sebanyak 4,550 kali lebih besar dibandingkan responden yang tidak terpapar media massa.

Paparan media massa baik cetak ataupun elektronik mempunyai pengaruh terhadap remaja untuk melakukan hubungan seksual pranikah. Paparan informasi seksualitas dari media massa yang bersifat pornografi dan porno aksi dapat menjadi referensi yang tidak mendidik remaja. Remaja yang dalam periode ingin tau, dan ingin mencoba, akan meniru apa yang di lihat dan di dengarnya dari media massa tersebut. ${ }^{27}$ 
Menurut penelitian yang dilakukan oleh Nazli Halwani Pohan dari 66 responden yang terpapar media massa, sebanyak 28 orang $(62,2 \%)$ responden yang menikah dini dan 38 orang $(42,22 \%)$ responden yang belum menikah. Sedangkan dari 69 responden yang tidak terpapar media massa, sebanyak 17 orang $(37,78 \%)$ responden yang menikah dini dan 52 orang $(57,78 \%)$ responden yang belum menikah. Berdasarkan hasil uji Chi-square antara variabel media massa dengan pernikahan dini, diperoleh nilai $p$-value $0,0425<\mathrm{a}(0,05)$ yang artinya H0 ditolak, sehuingga dapat disimpulkan ada hubungan yang bermakna antara media massa terhadap pernikahan dini pada remaja putri. ${ }^{18}$

Penelitian yang sejalan yang dilakukan oleh Siti Zubaidah Harahap dari 50 responden yang terpapar media massa sebanyak, 21 orang $(42,0 \%)$ responden yang menikah usia muda dan 29 orang $(58,0 \%)$ responden yang belum menikah. Sedangkan dari 45 responden yang tidak terpapar media massa sebanyak 4 orang $(8,9 \%)$ responden yang menikah usia muda dan 41 orang $(91,1 \%)$ responden yang belum menikah. Berdasarkan hasil uji Chi-square antara variabel paparan media massa dengan pernikahan usia muda pada remaja, diperoleh nilai $p$ value $0,0001<\mathrm{a}(0,05)$ yang berarti dapat disimpulkan ada hubungan yang bermakna antara paparan media massa terhadap pernikahan usia muda pada remaja. ${ }^{3}$

Penelitian yang sejalan juga dilakukan oleh Rotua Simanjuntak yang menyatakan ada hubungan antara media massa dengan pernikahan usia dini pada remaja putri. Hal ini dibuktikan dari hasil perhitungan uji korelasi dapat diketahui bahwa nilai $p$-value $0,045<a$ $(0,05)$ serta OR sebesar 2,254 yang berarti bahwa remaja putri yang terpapar media massa mempunyai resiko 2,254 kali menikah dini dibandingkan remaja putri yang tidak terpapar media massa. ${ }^{20}$

Berdasarkan paparan yang telah dijelaskan, peneliti mengungkapkan bahwa peran keluarga diperlukan untuk memantau dan mendampingi anaknya dalam penggunaan media massa, baik media cetak, elektronik, dan internet agar tidak terpapar gambar, video dan situs pornografi, dan orang tua dapat memberikan penjelasan kepada anaknya mengenai informasi kesehatan reproduksinya termasuk masalah seksual dan pada akhirnya tidak perlu lagi mencari informasi terkait seks dari media massa.

\section{Pandangan dan Kepercayaan Terhadap Pernikahan Usia Dini pada Remaja}

Hasil uji Chi-square menunjukan hubungan pandangan dan kepercayaan terhadap pernikahan usia dini pada remaja diperoleh nilai $p$-value $=0,002$ artinya $p$-value $<a(0,05)$ sehingga dapat disimpulkan hipotesis nol (H0) ditolak dan hipotesis alternatif (Ha) diterima yang berarti ada hubungan yang signifikan antara pandangan dan kepercayaan terhadap pernikahan usia dini pada remaja. Hasil Uji Odds Ratio menunjukan nilai OR = 8,000 (95\% CI $=2,247-28,477$ ) artinya responden yang memiliki pandangan dan kepercayaan yang negatif akan meningkatkan resiko pernikahan usia dini sebanyak 8,000 kali lebih besar dibandingkan responden yang memiliki pandangan dan kepercayaan yang baik.

Pandangan dan kepercayaan merupakan suatu cara pandang atau persepsi seseorang mengenai kebiasaan, keyakinan atau kepercayaan seseorang yang diyakini benar adanya. Pandangan agama islam yang merupakan agama mayoritas yang menyatakan bahwa menikah pada usia muda bukanlah merupakan suatu yang dilarang agama dan dalam Islam tidak ada batasan usia untuk menikah yang penting adalah sudah mumayyiz (baligh dan berakal), sehingga sudah selayaknya di nikah kan. Menurut Yusuf, dalam islam pada dasarnya tidak ada keterangan yang jelas untuk membatasi usia/umur diperbolehkannya seseorang melaksanakan 


\section{SIMFISIS Jurnal Kebidanan Indonesia}

akad nikah. Hubungan antara laki-laki dan perempuan diatur secara terhormat dan berdasarkan saling ridho dengan dilangsungkannya upacara pernikahan. Karena dengan pernikahan seseorang akan terhindar dari perbuatan yang dilarang oleh agama seperti halnya seks bebas, sebab dengan cara pernikahan maka akan lebih efektif dan efisien untuk mencegah perbuatan zina, sehingga fenomena maraknya pernikahan di usia muda semakin banyak terjadi. ${ }^{3}$

Penelitian ini sejalan dengan teori yang ada, menurut pendapat Imam Muhammad Syirazi dan juga Asadullah Dastani Benisi, budaya pernikahan dini dibenarkan dalam islam dan ini sudah menjadi norma muslim sejak mulai awal islam. Pernikahan dini menjadi kebutuhan vital khususnya akan memberikan kemudahan dan tidak dibutuhkan studi terlalu mendalam untuk melakukannya. Ibnu Syubromah menyikapi pernikahan yang dilakukan Nabi SAW dengan Aisyah yang saat itu masih berumur 6 tahun dan ia menganggap jika hal ini adalah ketentuan khusus untuk Nabi SAW yang tidak dapat ditiru oleh umat Islam.

Akan tetapi menurut pakar mayoritas hukum islam memperbolehkan pernikahan dini dan menjadi hal yang lumrah dikalangan para sahabat dan bahkan sebagian ulama melumrahkan hal tersebut yang merupakan hasil interpretasi Surah At-Talaq ayat 4. "Dari Aisyah ra (menceritakan) bahwasannya Nabi SAW menikahinya pada saat beliau masih anak berumur 6 tahun dan Nabi SAW menggaulinya sebagai istri pada umur 9 tahun dan beliau tinggal bersama pada umur 9 tahun pula" (Hadis Shohih Muttafaq 'alaihi). "Dan perempuanperempuan yang tidak haid lagi (monopause) di antara perempuan-perempuanmu jika kamu ragu-ragu (tentang masa iddahnya) maka iddah mereka adalah tiga bulan; dan begitu (pula) perempuan-perempuan yang tidak haid. Dan perempuan-perempuan yang hamil, waktu idah mereka itu ialah sampai mereka melahirkan kandungannya. Dan barang siapa yang bertakwa kepada Allah niscaya Allah menjadikan baginya kemudahan dalam urusannya". [QS At-Talaq :4]

Hukum asal sunnah sendiri bisa berubah menjadi wajib atau haram berdasarkan dari kondisi orang yang akan membangun rumah tangga dalam islam. Jika ia tidak bisa menjaga kesucian atau 'iffah dan akhlak kecuali dengan menikah, maka hukum menikah menjadi wajib untuknya. Hal ini dikarenakan kesucian dan akhlak menjadi hal yang wajib untuk semua umat muslim. Hukum bisa berubah menjadi haram jika pernikahan dilakukan karena alasan ingin menyakiti istri atau karena harat dan sesuatu yang bisa menimbulkan bahaya untuk agama dan tidak melaksanakan kewajiban sebagai suami isteri. ${ }^{28}$

Berdasarkan paparan yang telah dijelaskan, peneliti mengungkapkan bahwa peran orang tua untuk lebih memperhatikan usia menikah melainkan usia yang ideal untuk mulai bereproduksi dan dibutuhkan peran dari tokoh agama untuk menanamkan nilai-nilai moral dan juga agama pada remaja agar terhindar dari pergaulan bebas yang dapat merugikan diri sendiri dan pada akhirnya dapat menyebabkan pernikahan usia dini.

Dari determinan yang memiliki 5 variabel yang paling berpengaruh adalah variabel pandangan dan kepercaayan. Disini kita tahu, sulit mengubah pola pikir atau sistem kepercayaan yang dianut dimasyarakat tentang pernikahan dini dimana didalam agama islam tidak dijelaskan batas usia menikah, akan tetapi hal itu dilihat ketika seseorang mencapai akil baligh, menikah juga menurut islam adalah ibadah. Sehingga ini mendukung dan dapat meningkatkan banyak dampak maupun resiko dari pernikahan usia dini yang sering dialami oleh wanita terutama pada aspek kesehatan. Untuk mencegah terjadinya pernikahan usia dini kita bisa melakukan pendekatan dan kerjasama kepada orang tua, keluarga, tokoh masyarakat, 


\section{SIMFISIS Jurnal Kebidanan Indonesia}

Volume 01, Nomor 02, November 2021

tokoh agama yang dapat membantu mencegah terjadinya pernikahan dini serta dapat membantu menekan terjadinya kenaikan angka kematian ibu dan angka kematian bayi.

\section{Kesimpulan}

Berdasarkan hasil analisis data dan pembahasan yang telah diuraikan bahwa: Ada hubungan yang signifikan antara faktor ekonomi terhadap pernikahan usia dini pada remaja dengan $p$-value sebesar 0,013 dan Odds Ratio $(\mathrm{OR})=5,444$ (95\% CI=1,584-18,714). Ada hubungan yang signifikan antara faktor lingkungan terhadap pernikahan usia dini pada remaja dengan $p$-value sebesar 0,026 dan Odds Ratio (OR)=4,453 (95\% CI=1,353-14,653). Ada hubungan yang signifikan antara sosial budaya terhadap pernikahan usia dini pada remaja dengan $p$-value sebesar 0,027 dan Odds Ratio $(\mathrm{OR})=4.444$ (95\% CI=1,337-14,769). Ada hubungan yang signifikan antara media massa terhadap pernikahan usia dini pada remaja dengan $p$-value sebesar 0,028 dan Odds Ratio $(\mathrm{OR})=4,550$ (95\% CI=1,335-15,503). Ada hubungan yang signifikan antara pandangan dan kepercayaan terhadap pernikahan usia dini pada remaja dengan $p$-value sebesar 0,002 dan Odds Ratio (OR)=8,000 (95\% CI=2,247$28,477)$. Dengan demikian dapat disimpulkan bahwa terdapat hubungan yang signifikan dari determinan pernikahan usia dini pada remaja.

\section{Konflik Kepentingan}

Peneliti menyatakan bahwa penelitian ini independen dari konflik kepentingan individu dan organisasi.

\section{Ucapan Terima Kasih}

Terimakasih kepada seluruh pihak yang telah berkontribusi membantu proses penelitian ini.

\section{Pendanaan}

Sumber pendanaan diperoleh dari peneliti.

\section{Daftar Pustaka}

1. Fadlyana E, Shinta L. Pernikahan usia dini dan permasalahannya. J Sari Pediatr Ilmu Kesesehatan FK Univ Padjajaran. 2016;11(2):136-141. doi:10.14238/sp11.2.2009.136-41

2. Pohan NH. Faktor yang berhubungan dengan pernikahan usia dini terhadap remaja putri. J Endur Akad Kebidanan Umi Bagan Batu. 2017;2(3):424-425. doi:10.22216/jen.v2i3.2283

3. Harahap SZ. Pengaruh faktor internal dan eksternal terhadap terjadinya pernikahan usia muda pada remaja di desa seumadam kecamatan kejuruan muda kabupaten aceh tamiang tahun 2014. Published online 2014.

4. Wirdianto T, Al HY, Ambar DS, Setio N, Siti L, Riyadi S et al. Profil anak Indonesia 2018. In: Dendi R, Indra MS, Maret TN, Wachyu W, Awaludin A, Hasnani R et al, ed. Psikologi Perkembangan. Kementerian Pemberdayaan Perempuan dan Perlindungan Anak; 2019:1-378. doi:10.1017/CBO9781107415324.004

5. Welle D. UNICEF: 115 juta anak laki-laki di dunia menikah di bawah umur. Published online October 2020.

6. Hakiki G, Asnita U, Maarif IK, Sugeng S, Muhammad B, Widya L et al. Pencegahan perkawinan anak. In: Sahrizal N, Piping SH, Amiek C, Idha S, Bheta AA, Emillie M et al, ed. Pencegahan Perkawinan Anak Percepatan Yang Tidak Bisa Ditunda. Badan Pusat Statistik; 2020:1-44.

7. Sabariman H. Peran klebun babine dalam upaya pencegahan pernikahan usia dini di desa ponteh kecamatan galis kabupaten pamekasan. J Gend Stud Progr Stud S2 Sains Univ Brawijaya Malang. 2019;12(2):317-4.

8. Nasihuddin AAA. Data BPS: angka pernikahan dini di kalimantan selatan tertinggi di Indonesia.October 


\section{SIMFISIS Jurnal Kebidanan Indonesia}

Volume 01, Nomor 02, November 2021

2020.

9. Asri MGU. Kepala bkkbn ajak asosiasi media siber untuk menekan angka pernikahan dini.April 2019.

10. Yusuf. Buku Daftar Nikah. (Tim, ed.). KUA Kecamatan Pontianak Barat; 2019.

11. Meitria SN, Fauzie R, Fahrini Y, Budi S, Atikah R, Dian R et al. Klinik Dana (Klinik Muda Berencana) Sebagai Upaya Pencegahan Pernikahan Dini. 1st ed. (Meitria SN, Fauzie R, Fahrini Y, Budi S, Atikah R, Dian R et al, ed.). CV Mine; 2018.

12. Damayanti A. Analisis faktor predisposisi yang berhubungan dengan perilaku masyarakat dalam pemberantasan sarang nyamuk (psn) di rw 004 kelurahan nambangan kidul kecamatan mangunharjo kota madiun tahun 2017. Published online 2017.

13. Jatmiko AA. Determinan perilaku sibling. Published online 2015.

14. Fitria Y. Sikap siswa terhadap sosial budaya di kabupaten banyuwangi (studi deskriptif analisis). J Semin ASEAN 2nd Psychol Humanit (C) Psychol Forum UMMsychology Forum Univ Muhammadiyah Malang. Published online 2016:19-20.

15. Luis C M. Vygotsky \& Education Instructional Implications and Applications of Sociohistorical Psychology. Cambridge University Press; 2009.

16. Ticoalu TW. Pemberdayaan media massa dalam meningkatkan pendidikan politik pada masyarakat kelurahan wewelen kecamatan tondano barat kabupaten minahasa. e-journal Acta Diurna Univ Sam Ratulangi Manad. 2015;IV(3):1-15.

17. Masturoh I, Nauri AT. Bahan ajar rekam medis dan informatika kesehatan (rmik) pusat pendidikan sumber daya manusia kesehatan badan pengembangan dan pemberdayaan sumber daya manusia kesehatan edisi tahun 2018. In: Asmo BD NS, ed. Metodologi Penelitian Kesehatan. 1st ed. Kementerian Kesehatan Republik Indonesia; 2018:1-307. doi:10.16309/j.cnki.issn.1007-1776.2003.03.004

18. Pohan NH. Faktor yang berhubungan dengan pernikahan usia dini terhadap remaja putri. $J$ Endur. Published online 2017.

19. P. I Nyoman Adi PLI. Faktor - faktor yang mempengaruhi pernikahan usia dini pada remaja wanita. $J$ Keperawatan Suaka Insa. 2018;3 No 2 (20:1-14.

20. Rotua S dkk. Faktor - faktor yang berhubungan dengan pernikahan usia dini pada remaja putri di kecamatan tanjung rejo percut sei tahun 2017. Reprod Health. 2017;2:64-77.

21. Kharisma N. Pengaruh motivasi, prestasi belajar, status sosial ekonomi orang tua dan lingkungan teman sebaya terhadap minat melanjutkan pendidikan ke perguruan tinggi pada siswa kelas XII kompetensi keahlian akuntansi di smk negeri se-kota semarang tahun ajaran 2015. Published online 2015.

22. Fitrianis N. Hubungan Tingkat Pengetahuan Remaja Dan Lingkungan Pergaulan Terhadap Pernikahan Dini Di Desa Samili Tahun 2017. Pendidik Dasar. 2018;2(1):109-122.

23. Resti A. Faktor - faktor yang berhubungan dengan kejadian pernikahan dini pada remaja putri didusun III tahun 2018. Pernikahan Dini. 2018;02.

24. Eka YH. Faktor - faktor yang berhubungan dengan pernikahan usia dini pada remaja putri di kecamatan tambusai utara kabupaten rokan hulu. J Pernikahan Dini I. Published online 2014.

25. Arikhman N. Faktor yang mempengaruhi pernikahan usia dini di desa baru kabupaten kerinci. J Endur Progr Stud Kesehat Masy STIKes Syedza Saintika Padang. 2019;4(3):470-0. doi:10.22216/jen.v4i3.4614

26. Nova A. Faktor Yang Mempengaruhi Pernikahan Usia Dini Di Desa Baru Kabupaten Kerinci. J Endur Progr Stud Kesehat Masy STIKes Syedza Saintika Padang. 2019;4(3):470.

27. Rusliman. Pengaruh media massa dalam praktek pernikahan dini di kecamatan pantan cuaca gayo lues. Published online 2019.

28. Khasanah U. Pandangan islam tentang pernikahan dini. J Pendidik dan Pembelajaran Dasar Jur Pai Fak Tarb Dan Kegur IAIN Raden Intan Lampung. 2014;1(2):306-318. 